\title{
Habitat creation and biodiversity maintenance in mangrove forests: Teredinid bivalves as ecosystem engineers
}

Substantial amounts of dead wood in the intertidal zone of mature mangrove forests are tunnelled by teredinid bivalves. When the tunnels are exposed, animals are able to use tunnels as refuges. In this study, the effect of teredinid tunnelling upon mangrove forest faunal diversity was investigated. Mangrove forests exposed to long emersion times had fewer teredinid tunnels in wood and wood not containing teredinid tunnels had very few species and abundance of animals. However, with a greater cross-sectional percentage surface area of teredinid tunnels, the numbers of species and abundance of animals was significantly higher. Temperatures within teredinid-attacked wood were significantly cooler compared with air temperatures, and animal abundance was greater in wood with cooler temperatures. Animals inside the tunnels within the wood may avoid desiccation by escaping the higher temperatures. Animals co-existing in teredinid tunnelled wood ranged from animals found in terrestrial ecosystems including centipedes, crickets and spiders, and animals found in subtidal marine ecosystems such as fish, octopods and polychaetes. There was also evidence of breeding within teredinid-attacked wood, as many juvenile individuals were found, and they may also benefit from the cooler wood temperatures. Teredinid tunnelled wood is a key low-tide refuge for cryptic animals, which would otherwise be exposed to fishes and birds, and higher external temperatures. This study provides evidence that teredinids are ecosystem engineers and also provides an example of a mechanism whereby mangrove forests support intertidal biodiversity and nurseries through the wood-boring activity of teredinids. 
1 Ian W. Hendy*, Laura Michie, \& Ben W. Taylor

2 Institute of Marine Sciences, The University of Portsmouth, UK

3 *corresponding author

4 email: ian.hendy@port.ac.uk

5 phone: $+44(0) 2392845799$ 


\section{Introduction}

$7 \quad$ Mangrove ecosystems have long been considered as low bio-diverse habitats (Duke et al.

8 1998; Alongi 2002), especially when compared with other tropical marine ecosystems, for

9 example, coral reefs (Connell 1978; Knowlton et al. 2010). However, mangrove forests provide a

10 variety of niches to creatures that depend upon these coastal ecosystems (Nagelkerken et al.

11 2008). Animals commonly described from mangrove forests are found in a broad range of

12 different biomes, such as aquatic sesarmid crabs, which break down and recycle much of the leaf

13 litter (Robertson 1990), and terrestrial beetles that process large woody debris (LWD) in the high-

14 to mid-intertidal areas of the forests (Feller 2002). Thus, mangrove forests host organisms

15 commonly found in terrestrial and aquatic habitats (Nagelkerken et al. 2008). Principally, within

16 the mangrove environment, there are three main substrata that fauna are able to exploit;

17 sediments (Kristensen 2007), root structures (Ellison and Farnsworth 1990; Ellison et al. 1996)

18 and LWD (Cragg and Hendy 2010; Hendy et al. 2013).

19 Studies of tropical habitat structure have shown that the structural complexity maintains

20 the greatest level of biodiversity (Gratwicke and Speight 2005; Fuchs 2013). Mangrove forests

21 provide a wide range of niches maintained by substrata such as mangrove roots, which maintain a

22 high level of biodiversity (Gratwicke and Speight 2005). The complexity of root structures

23 provides cover and protection for small and juvenile fish communities (Ronnback et al. 1999;

24 Correa and Uieda 2008; Wang et al. 2009) that decrease their risk of becoming predated upon

25 (Verweij et al. 2006; Tse et al. 2008; MacDonald et al. 2009). The structural heterogeneity

26 provided by the roots may either impede the movement of hunting predatory fish or the prey-fish

27 are able to reduce their visibility by using the roots to hide behind (Laegdsgaard and Johnson

28 2001; Kruitwagen et al. 2010) - therefore the diversity of animals and abundance of individuals

29 are largely considered to be attributed to deterministic factors such as habitat complexity (Syms 
and Jones 2000). Indeed, habitat complexity is one of the most important factors structuring

31 faunal assemblages - acting as a decoupling mechanism in predator-prey interactions (Firstater et

32 al. 2011; Kovalenko et al. 2012).

33 Although mangrove roots provide a nursery habitat, little is known about the mangrove

34 faunal communities relying upon fallen wood as a habitat; in particular wood that has been

35 attacked by teredinid bivalves. Teredinids create many tunnels in LWD (Filho et al. 2008). When

36 the teredinids die, the tunnels may support biodiversity when vacant, for animals to exploit

37 (Cragg and Hendy 2010, Hendy et al. 2013). This means that LWD may provide an important

38 ecosystem service as a bio-diverse micro-habitat within intertidal areas (Storry et al. 2006). It is

39 known that when trees fall into freshwater ecosystems they attract a high level of biodiversity

40 (Roth et al. 2007). The riparian zone is important as this habitat sustains many aquatic animals.

41 Thus, LWD serves as an important link between terrestrial and aquatic ecosystems (Roth et al.

42 2007).

This study aims to investigate the ecological role of teredinid bivalves in creating niches -

44 tunnels for fauna, and if a greater number of tunnels maintain greater abundances of animals and

45 numbers of species within LWD from Indonesian mangrove ecosystems. Thus, the engineered

46 internal structural complexities within dead wood created by teredinid tunnels were quantified

47 and measured, and then correlated with counts of animal abundance and number of species - to

48 determine if increases of habitat complexity created by teredinids can enhance animal abundance

49 and numbers of species. Teredinids may then be considered as allogenic ecosystem engineers.

50 Such organisms modify the environment by transforming living or non-living material (e.g.

51 LWD) from physical state to another, via mechanical processes to maintain and create habitat

52 (Jones et al. 1994). 
To increase biodiversity the engineering species, in this case, teredinids must create

54 conditions not present elsewhere in the landscape, and other animals must be able to live in the

55 engineer-created patches (Wright et al. 2002). Thus, this study tested the hypotheses that;

56

57

58

59

60

\section{Materials and methods}

62

\section{Assessing the effect of teredinid tunnelling on LWD in mangrove forests}

The abundance of animals and species within teredinid tunnels was estimated from five

64 mangrove forests Langira, Kaluku, Loho, One Onitu and the Gili forest in East Sulawesi,

65 Indonesia $\left(05^{\circ} 12^{\prime}-06^{\circ} 10^{\prime} \mathrm{S}, 123^{\circ} 20^{\prime}-124^{\circ} 39^{\prime} \mathrm{E}\right)$. Within each forest, LWD samples were

collected from five transects extending from the strandline out to the seaward edge. Each transect

67 was $4 \mathrm{~m}$ wide, and transects were between 50 and $100 \mathrm{~m}$ apart. For details of transect lengths and

68

69

70

71 chosen at random to compare the abundance of animals, numbers of species and percentage

72 surface area of tunnels. The proportion of sampled wood from the total volume of fallen wood in

73 each of the transects from each mangrove forest ranged from 0.4 to $5.9 \%$ of the total volume 
74 (Table 2B). Counts of animals removed from within the tunnels in each sample of wood were

75 estimated to 1 litre and were expressed as numbers per litre of wood.

76 The LWD samples were carefully broken apart and all animals were collected and

77 identified. The percentage of teredinid tunnels was used to categorise the level of teredinid attack,

78 by measuring the percentage of the surface occupied by teredinid tunnels across the longitudinal

79 section of each LWD sample using the digital analysis package, Image Tool Version 3.00 (The

80 University of Texas Health Science Centre at San Antonio). Within each mangrove forest, the

81 substratum type that each LWD sample was collected from was noted. Ground water salinities

82 were measured using a Bellingham and Stanley E-Line Aquatic hand-held refractometer, and the

83 distance from the land (strandline) of each LWD sample was recorded. To calculate emersion

84 time within each mangrove forest, at five metre intervals the level of high tide was marked on

85 mangrove trees using high visibility string. This was repeated from the strandline and extending

86 out to the seaward edge. At low tide, the distance from the substratum to the mark on the tree was

87 measured and then subtracted from the height of high tide as given in the Indonesian tide tables.

88 Emersion times were estimated by relating their tidal height to data in regional tide tables.

89 The field study was agreed and approved by Operation Wallacea under permit,

90 04/TKPIPA/FRP/SM/IV/2011.

\section{In situ internal wood and ambient air temperature measurements}

92 A calibrated thermocouple thermometer (Oakton WD-35427-00 Temp 10 Type J) was

93 used to measure internal temperatures of 27 in situ teredinid-attacked logs and outside air

94 temperatures in the Langira mangrove forest. The thermometer had two temperature probes: one

95 probe was placed upon the wood surface and the other placed in the centre of the wood. The 
96 wood was very quickly split open and the probe placed in to the centre before closing the split

97 section. After five minutes of placing both probes in position, the temperature was recorded. A

98 sample of wood from each piece of wood that temperatures were recorded from was taken back

99 to the laboratory, and all animals within the vacant teredinid tunnels within the wood sample

100 were removed and counted.

\section{Statistical data analysis}

102 The univariate and non-parametric multivariate techniques of the distance-based linear

103 modelling package (DistLM) contained in PRIMER 6.1 (PrimerE Ltd: Plymouth Routines in

104 Multivariate Ecological Research) were used to explore the animal abundance and number of

105 species removed from vacant teredinid tunnels in wood across five mangrove forests, and tested

106 against environmental variables: salinity, substrate type (mud, sand, and calcareous mud),

107 distance from land (D.F.L), percentage surface area of teredinid attack, mangrove area and size of

108 wood sample. DistLM was employed to verify relationships between the abundance of fauna and

109 number of species removed from teredinid tunnels across all sites with the environmental

110 variables. DistLM produces a marginal test, which assesses the variation each predictor

111 (environmental variable) has on its own, and a sequential test, assessing the variation of all the

112 environmental variables (McArdle and Anderson 2001). The most parsimonious model was

113 identified using the selection criterion $\mathrm{R}^{2}$. Distance-based redundancy analyses (dbRDA) were

114 used for visualizing the results as an ordination, constrained to linear combinations of the

115 environmental variables. The DistLM was based on abundance and environmental data, with

1164999 permutations.

117 A 1-way ANOVA was used to test for differences; of the number of species and 
118 abundance of animals in wood with different percentage surface areas of teredinid tunnels; site-

119 specific differences of the percentage surface area of teredinid tunnels; and emersion times

120 between mangrove sites. Tukey's post-hoc pairwise comparison tests separated values into

121 statistically distinct subsets for ANOVA. All data were checked for normality, residuals were

122 inspected to ensure that assumptions for ANOVA were not compromised. Regression analyses

123 were used to test for relationships of animal abundance and numbers of species within vacant

124 teredinid tunnels with environmental factors: distance from the land, volume of LWD, percentage

125 surface area of teredinid tunnels and ambient air- and within wood- temperatures. A Pearson

126 Correlation was used to test for relationships with internal wood cooling and the abundance of

127 fauna within wood. A Paired t-test was used to determine temperature differences within wood

128 and ambient air temperatures. Count data were square root transformed and all percentage data

129 were arcsine transformed. Statistical analyses were performed using MINITAB (MINITAB Inc,

130 version 13.20).

\section{Results}

In total, 36 genera, amounting to 1621 individuals were found in vacant teredinid tunnels

133 inside wood, which consisted of 7 phyla across the five mangrove forest localities (Table $2 \mathrm{~A}$ and 134 B).

135 The kinds of animals found inhabiting teredinid tunnels in LWD samples were diverse,

136 and ranged from terrestrial species, such as coleopteran larvae and crickets (Insecta), intertidal

137 species including reef spiders, Desis martensi (Arachnida) and mussels (Bivalvia) and aquatic

138 species including moray eels, Gymnothorax richardsonii (Actinopterygii) and octopods

139 (Cephalopoda). In addition, different stages of animal development were found - as juveniles of

140 many species were also found in the teredinid tunnels (Fig. 1). 
$14228 \%$ of the similarity with the abundance of animals and numbers of species removed from

143 tunnelled wood across all mangrove sites (Fig. 2A, B and C, DistLM marginal test, $F=74.2, p=$

$144<0.001)$. No significant correlations were found with the abundance of animals and numbers of

145 species with substrate type, LWD sample volume (L vol), site area, distance from land (D.F.L)

146 and salinity (Fig. 2B, sequential test, $p=>0.05$ ). The most parsimonious model for the five sites

147 explained $31 \%$ of the variation, with percentage surface area of teredinid attack, again explaining

$14828 \%$ of the similarity across all sites (DistLM sequential test, $F=74.2, p=<0.001$ ).

149 No difference was found with the abundance of animals in wood when tested with

150 salinity, increasing distance from the land and with the total area of the mangrove forest (Multi-

151 regression, $p=>0.05$ ). However, a significant difference was found with greater volumes of

152 LWD when correlated with greater numbers of species $\left(F_{1,78}=9, p=<0.01\right)$, nonetheless a low

153 relationship was found, $\mathrm{R}^{2}(\mathrm{adj})=10 \%$, although no significant difference was found with greater

154 volumes of LWD when correlated with abundance of animals $\left(F_{1,78}=3.5, p=>0.05, \mathrm{R}^{2}(\operatorname{adj})=\right.$

$1553 \%$ ). The strongest relationship with best fit and significance for the numbers of species and

156 abundance of animals in LWD was the percentage surface area of teredinid tunnels (Fig. 3A, $F_{1,78}$

$157=35.6, p=<0.001, \mathrm{R}^{2}(\operatorname{adj})=30.5 \%$, and Fig. $3 \mathrm{~B}, F_{1,78}=33.8, p=<0.001, \mathrm{R}^{2}(\operatorname{adj})=29.4 \%$

158 respectively).

159 The lowest number of species was found in wood with percentage surface area of

160 teredinid tunnels ranging from $0-19.9 \%$, with $1.5 \pm 0.3$ species. The greatest number of species

161 was found in wood with more than $60 \%$ surface area of teredinid tunnels, with $10.1 \pm 1.0$ species

162 (Fig. 3C, 1-way ANOVA, $F_{3,76}=13.9, p=<0.001$, mean \pm SE). The same significant pattern

163 with the abundance of animals was found in LWD with different levels of percentage surface area

164 of teredinid tunnels, with $2.3 \pm 0.4$ animals in wood with $0-19.9 \%$ surface area of tunnels, 
165 compared with $27 \pm 6.9$ animals in wood with more than $60 \%$ surface area of tunnels (Fig. 3D,

$166 F_{3,76}=14, p=<0.001$, mean $\left.\pm \mathrm{SE}\right)$.

167 Although a strong correlation with the percentage surface area of teredinid attack was

168 found with the abundance of animals and number of species in tunnelled wood across all

169 mangrove sites, differences of the percentage surface area of teredinid attack were found between

170 the mangrove sites (Fig. 4A, 1-way ANOVA, $F_{4,95}=3.6, p=<0.01$, mean $\pm \mathrm{SE}$ ). The percentage

171 surface area of teredinid attack between three of the mangrove forests was statistically

172 indistinguishable, while the percentage surface area of teredinid attack in the Gili forest was

173 significantly lower than Langira, Loho and Kaluku, 8.7\% $\pm 3.5 \%, 16.5 \% \pm 4 \%, 23.9 \% \pm 5.3 \%$

174 and $32.3 \% \pm 5.6 \%$ respectively. The greatest degree of teredinid-tunnelling was found in LWD

175 samples from the Kaluku mangrove forest.

176 The lowest emersion times in the One Onitu, Langira, Loho and Kaluku forests ranged

177 from $7.1 \pm 0.5$ hours per day to $7.7 \pm 0.3$ hours per day (mean $\pm \mathrm{SE}$ ). However, the emersion time

178 recorded in the Gili mangrove was significantly greater compared with all other forests, with a

179 mean emersion time of $12.5 \pm 0.2$ hours per day (Fig. 4B, 1 -way ANOVA, $F_{4,156}=34.3, p=<$

1800.001 , mean $\pm \mathrm{SE})$.

181 The Gili forest had the lowest abundance (6.6 \pm 1.6 animals) and number of species per

182 litre volume $(3.1 \pm 0.7$ species $)$ removed from the LWD samples, but Kaluku had the greatest

183 abundance $(44.7 \pm 16.4$ animals $)$ and number of species $(11.8 \pm 3.6$ species $)$ within teredinid-

184 attacked LWD (Fig. 4C and D, 1-way ANOVA, $F_{4,95}=3.75, p=<0.01$ and $F_{4,95}=2.13, p=>$

1850.05 , mean $\pm \mathrm{SE}$ respectively).

186 Temperature measurements within wood were significantly cooler compared with the

187 ambient air temperature outside of the wood (Paired t-test, $p=<0.001$ ). As ambient air

188 temperature increased, internal wood temperatures were significantly cooler, with the greatest

189 difference being $-9.5^{\circ} \mathrm{C}$ (Fig. 5, Regression analysis $\mathrm{R}^{2}=82 \%, F_{1,25}=116, p=<0.001$ ) and the 
190 abundance of animals within wood increased with cooler temperatures (Regression analysis $\mathrm{R}^{2}=$

$\left.19119 \%, F_{1,25}=5.9, p=<0.05\right)$. The cooler the internal temperature within wood relative to ambient 192 air temperature, the greater the abundance of animals found within teredinid-attacked wood 193 (Pearson Correlation, $-0.5, p=<0.01$ ).

\section{Discussion}

195

196

The data from this study supports our hypotheses that vacant teredinid tunnels benefit many species in Indonesian mangrove forests, and a greater surface area of tunnels will maintain a greater number of species and abundance of fauna. Animal diversity is positively correlated with increasing habitat complexity (Petren and Case 1998; Gratwicke and Speight 2005; Saha et al. 2009). If it was not for the tunnels created by teredinids, LWD would have significantly fewer animals, and a reduced nursery function, important for species such as octopods, and dartfish (Hendy et al. 2013). Thus, the fauna collected from the teredinid-attacked LWD in the mangrove forests from this study are maintained by a habitat-specific structure - teredinid tunnels inside LWD.

Large pieces of woody debris within aquatic ecosystems are important constituents in the structure and complexity of waterways and will probably become colonised by a wide variety of animals (Hilderbrand et al. 1997; Storry et al. 2006; Hendy et al. 2013). Fallen wood represents a vital resource providing a spatial subsidy for many animals within the aquatic ecosystem (McClain and Barry 2014). Wood enhances habitat complexity (Shirvell 1990; Brooks et al. 2004), the deposition of sediments, and the retention of organic matter (Bilby and Likens 1980; Smock et al. 1989). With the removal of wood however, sediment discharge will increase and a reduction of ecosystem-level habitat structural complexity will occur (Larson et al. 2001; Brooks et al. 2004). Large woody debris is therefore an important component within aquatic ecosystems 
213 (Shields et al. 2006). Thus, a major threat to mangrove ecosystems is wood harvesting (Valiela et

214 al. 2001; Duke et al. 2007; Sanchirico and Mumby 2009), which could reduce ecosystem-level

215 mangrove faunal diversity due to the reduced wood volume (Benke et al. 1985; Wright and

216 Flecker 2004; Hendy et al. 2013) and lack of niches otherwise created by teredinids.

217

Indeed, the results from this study corroborate previous research that LWD does increase

218 animal diversity (Everett and Ruiz 1993; Wright and Flecker 2004). Teredinids create niches as

219 they consume LWD, by creating tunnels for a wide range of animals - but only when those

220 tunnels become vacant. As the number of teredinid tunnels increase within LWD, the abundance

221 and diversity of animals will become greater. The great amounts of animal abundance and

222 number of species found within increasing numbers of teredinid tunnels may likely be due to a

223 higher proportion of refuges from predation (Willis et al. 2005; Hendy et al. 2013). For example,

224 the refuge provided by woody detritus is exploited by grass shrimp, as LWD significantly reduces

225 their risk of predation from predatory fish (Everett and Ruiz 1993). Vulnerable species have more

226 options for avoiding and escaping potential predation in habitats containing a greater number of

227 niches. Structurally complex habitats may also reduce visual contact, encounter rates and

228 aggressive behaviour between competitors (Jones et al. 2001; Willis et al. 2005).

229

Cryptic niches are typically exploited by animals to avoid predation (Ruxton et al. 2004),

230 and animals may also exploit LWD to avoid extreme air temperatures. Many areas of the

231 mangrove environment may be affected by rapid fluctuations in temperature (Taylor et al. 2005;

232 Bennett 2010). Yet, as air temperatures increased, the temperatures measured within LWD

233 became cooler creating a more desirable environment, and the abundance of animals in cooler

234 samples of LWD increased, which may also reduce their risks from desiccation.

235 Juvenile dartfish, Parioglossus interruptus, although able to tolerate high temperatures,

236 reside in the cooler teredinid tunnels during low tide (Hendy et al. 2013). Under laboratory

237 conditions, emerged LWD has an evaporative cooling process (Hendy et al. 2013). The fauna 
238 from this study may also benefit from a lower metabolic rate due to the significantly lower

239 temperatures within teredinid-attacked wood. Evidence of breeding within the tunnels was found,

240 and the cooler internal temperatures in LWD may provide a key refuge for juveniles to escape

241 high temperatures, as well as seeking relative safety from predation.

242 Temperature is the primary factor affecting development of invertebrates (Smith et al.

243 2013). Previous studies have shown that survival rates of developing veliger gastropods decrease

244 with increasing temperatures due to higher energetic demands of development at higher

245 temperatures (Smith et al. 2013). In this study, we found many octopods with egg sacs lining the

246 vacant teredinid tunnels. Octopods in Indonesian mangrove forests may benefit by residing inside

247 cooler teredinid tunnels, as metabolic processes may be slower in cooler temperatures, which

248 may prolong octopod embryonic development - producing stronger hatchlings (Robison et al.

249 2014).

250 The contribution of teredinid-attacked LWD, and the evaporative cooling within wood

251 (Hendy et al. 2013) to mangrove biodiversity maintenance is significant and remarkable.

252 Mangrove forest biodiversity is significantly enhanced by a large volume of teredinid attacked

253 LWD and the cooler temperatures in LWD may also enhance the development of eggs and

254 juveniles found in the teredinid tunnels. Non-tunnelled LWD has a limited number of species and

255 abundance of individuals due to the reduced niche availability. A lack of teredinid tunnels within

256 LWD maintains a reduced habitat complexity that may likely increase predator-prey encounters.

257 Differences in spatial structure will influence the frequency of interactions such as predation or

258 niche exploitation for animals (Warfe and Barmuta 2004; Nurminen et al. 2007). This may also

259 be the case for the spatial structure teredinid tunnels provide in LWD, which explains the sharp

260 change in animal assemblages and diversity of animals in LWD without tunnels when compared

261 to LWD with tunnels. 
263 samples are likely to contain additional resources and therefore greater numbers of species. To

264 effectively rule out the factor of sample size from this study all LWD samples were standardised

265 to the same volume and the same number of samples for each mangrove forest were used to test

266 for differences between localities. Even so, a greater amount of teredinid tunnels significantly

267 enhanced the animal abundance and numbers of species within LWD samples of the same 268 volume.

269 Teredinid tunnelling will also influence faunal diversity at the whole ecosystem level in 270 Indonesian mangrove forests. The lowest overall level of teredinid attacked LWD was recorded in 271 the Gili forest, which also had the lowest counts of animal abundance, number of species and 272 longest recorded emersion time when compared with the other four mangrove localities.

273 Teredinid tunneling is accelerated in mangrove forests with limited emersion times (Robertson 274 and Daniel 1989a; Kohlmeyer et al. 1995; Filho et al. 2008). Teredinids cannot tolerate regular 275 prolonged emersion such as LWD found in the high intertidal (Robertson 1990). In the mid- to 276 low- intertidal zones of a Rhizophora-dominated Australian mangrove forest, Robertson (1990)

277 found that half of the original woody mass of large fallen logs was consumed by teredinids within 278 two years, whereas, in the high- intertidal where teredinids were absent, only five percent of the 279 original mass of fallen logs had been lost over two years - explaining the reduced surface area of 280 teredinid tunnels measured within LWD from the Gili mangrove forest. This means that the 281 biggest effects are attributable to teredinid communities living at greater densities, such as that 282 found with the Kaluku mangrove forest, which had the highest degree of teredinid tunnelling in 283 LWD and the greatest abundance of animals and number of species within those tunnels.

284 Although LWD is essential for the biodiversity of both the specialist and more generalist animals 285 (Hilderbrand et al. 1997; Kappes et al. 2009; Hendy et al. 2013); teredinid tunnels will increase 286 the internal structural complexity within LWD and the tunnels significantly enhance biodiversity. 
288 cannot bore into the very hard, un-decayed wood. Thus, the large numbers of animals that rely on teredinid tunnels for predation refugia, or environmental buffering, or both, would not be as abundant, or may not even be present in the mangrove ecosystem if it were not for the tunnelled

291 wood. Based on the data presented here we classify teredinids as ecosystem engineers. A critical 292 characteristic of ecosystem engineering is that the engineered modifications, in this case teredinid 293 tunnels, must change the availability (quality, quantity and distribution) of resources utilised by 294 other fauna (Jones et al. 1994). Vacant teredinid tunnels within LWD in mangrove forests provide 295 many niches and the high complexity of tunnels lead to a broad range of co-existing animals 296 within LWD, especially in LWD with significantly greater surface area of tunnels.

297 Notwithstanding, the considerable turnover of large volumes of fallen wood by teredinids in 298 mangrove habitats - as the processed wood coupled with teredinid tissue and faecal matter may 299 significantly contribute to mangrove out-welling of nitrogen and carbon, improving the 300 productivity of near-shore adjacent ecosystems.

302 and heterogeneity within an ecosystem is a vital component for the interaction of co-existing 303 animals (Petren and Case 1998; Gratwicke and Speight 2005). Increasing habitat complexity may 304 reduce trophic interactions and subsequently increase ecosystem stability (Kovalenko et al. 305 2012). By comparison structurally simple habitats are not able to support the same levels of 306 biodiversity when compared with habitats consisting of high levels of complexity and rugosity

307 (Levin 1992). If mangrove harvesting and wood removal persists, then Indonesian mangrove 308 faunal abundance and diversity will be significantly reduced due to the lack of tunnel niches 309 created by teredinids.

\section{Acknowledgements}


311 We thank D. Smith, P. Mansell, and T. Coles for support during field activities. We also thank

312 Amat and Kundang, for their hard work and help with fauna collections. We also send our sincere

313 gratitude to R. S. K Barnes, for help with the identification of fauna. Finally, all authors of this

314 manuscript wish to give special thanks to each of the reviewers for their expert comments and

315 suggestions.

\section{Reference List}

317

318

319

320

321

322

323

324

325

326

327

328

329

330

331

332

333

334

335

336

337

338

339

340

341

342

343

344

345

346

347
Alongi MD. 2002. Present state and future of the world's mangrove forests. Environmental Conservation 29:331-349.

Benke AC, Henry III RL, Gillespie DM, and Hunter RJ. 1985. Importance of snag habitat for animal production in Southeastern streams. Fisheries 10:8-13.

Bennett WA. 2010. Extreme physiology of intertidal fishes of the Wakatobi. In: Clifton J, Unsworth RKF, and Smith DJ. (eds) Marine research and conservation in the Coral Triangle. Nova Science Publishers, Hauppage, New York.

Bilby ER, and Likens GE. 1980. Importance of organic debris dams in the structure and function of stream ecosystems. Ecology 6:1107-1113.

Brooks AP, Gehrke PC, Jansen JD, and Abbe TB. 2004. Experimental reintroduction of wood debris on the Williams River, NSW: geomorphic and ecological responses. River Research and Applications 20:513-536.

Connell JH. 1978. Diversity in tropical rain forests and coral reefs. Science 199:1302-1310.

Correa MDODA, and Uieda VS. 2008. Composition of the aquatic invertebrate fauna associated to the mangrove vegetation of a coastal river, analysed through a manipulative experiment. Pan-American Journal of Aquatic Sciences 3:23-31.

Cragg SM, Hendy IW. 2010. Mangrove Forests of the Wakatobi National Park. In: Clifton J, Unsworth RKF, and Smith DJ. (Eds.), Marine Research and Conservation in the Coral Triangle. Nova Science Publishers, Hauppauge, New York.

Duke NC, Ball MC, and Ellison JC. 1998. Factors influencing biodiversity and distribution gradients in mangroves. Global Ecology and Biogeography Letters 7:27-47.

Duke NC, Meynecke JO, Dittmann S, Ellison AM, Anger K, Berger U, Cannicci S, Dielle K, Ewel KC, Field CD, Koedam N, Lee SY, Marchand C, Nordhaus I, DahdouhGuebas F. 2007. A World without mangroves? Science 317:41-42.

Ellison AM, and Farnsworth EJ. 1990. The ecology of Belizean mangrove-root fouling communities. I. Epibenthic fauna are barriers to isopod attack of red mangrove roots. Journal of Experimental Marine Biology and Ecology 142:91-104.

Ellison AM, Farnsworth EJ, and Twilley RR. 1996. Facultative mutualism between red mangroves and root-fouling sponges in Belizean mangal. Ecology 77:2431-2444.

Everett RA, and Ruiz GM. 1993. Coarse woody debris as a refuge from predation in aquatic communities. An experimental test. Oecologia 93:475-486. 
Feller IC. 2002. The role of herbivory by wood-boring insects in mangrove ecosystems in Belize. Oikos 97:167-176.

Filho CS, Tagliaro CH, and Beasley CR. 2008. Seasonal abundance of the shipworm Neoteredo reynei (Bivalvia, Teredinidae) in mangrove driftwood from a northern Brazilian beach. Iheringia Series of Zoology 98:17-23.

352

353

354

355

356

357

358

359

360

361

362

363

364

365

366

367

368

369

370

371

372

373

374

375

376

377

378

379

380

381

382

383

384

385

386

387

388

389

390

391

392

393

394

395

396

Firstater FN, Hidalgo FJ, Lomovasky BJ, Ramos E, Gamero P, and Iribarne OO. 2011. Habitat structure is more important than important than nutrient supply in modifying mussel bed assemblage in an upwelling area of the Peruvian coast. Helgoland Marine Research 65:187-196.

Fuchs T. 2013. Effects of habitat complexity on invertebrate biodiversity. Immediate Science Ecology 2:1-10.

Gratwicke B, and Speight MR. 2005. The relationship between fish species richness, abundance and habitat complexity in a range of shallow tropical marine habitats. Journal of Fish Biology 66:650-667.

Hendy IW, Eme J, Dabruzzi TF, Nembhard RV, Cragg SM, and Bennett WA. 2013. Dartfish use teredinid tunnels in fallen mangrove wood as a low-tide refuge. Marine Ecology Progress Series 486:237-245.

Hilderbrand RH, Lemly AD, Dolloff A, and Harpster KL. 1997. Effects of large woody debris placement on stream channels and benthic macroinvertebrates. Canadian Journal of Fish and Aquatic Science 54:931-939.

Jones CG, Lawton JH, and Shachak M. 1994. Organisms as ecosystem engineers. Oikos 69:373-386.

Jones M, Mandelik Y, and Dayan T. 2001. Coexistence of temporally partitioned spiny mice: roles of habitat structure and foraging behaviour. Ecology 82:2164-2176.

Kappes H, Jabin M, Kulfan J, Zach P, and Top W. 2009. Spatial patterns of litter-dwelling taxa in relation to the amounts of coarse woody debris in European temperate deciduous forests. Forest Ecology and Management 257:1255-1260.

Knowlton N, Brainard RE, Fisher R, Moews M, Plaisance L, and Caley MJ. 2010. Coral reef biodiversity, in: Mcintyre AD. (Ed) (2010). Life in the world's oceans: diversity, distribution, and abundance. Oxford, Blackwell Publishing Ltd.

Kohlmeyer J, Bedout B, and Volkmann-Kohlmeyer B. 1995. Decomposition of mangrove wood by marine fungi and teredinids in Belize. Marine Ecology 16:27-39.

Kostylev VE, Erlandsson J, Ming MY, and Williams GA. 2005. The relative importance of habitat complexity and surface area in assessing biodiversity: Fractal application on rocky shores. Ecological Complexity 2:272-286.

Kovalenko KE, Thomaz SM, and Warfe DM. 2012. Habitat complexity: approaches and future directions. Hydrobiologia 685:1-17.

Kristensen E. 2007. Mangrove crabs as ecosystem engineers; with emphasis on sediment processes. Journal of Sea Research 59:30-43.

Kruitwagen G, Nagelkerken I, Lugendo BR, Mgaya YD, and Bonga W. 2010. Importance of different carbon sources for macroinvertebrates and fishes of an interlinked mangrove-mudflat ecosystem (Tanzania). Estuarine, Coastal and Shelf Science 88:464-472.

Laegdsgaard P, and Johnson C. 2001. Why do juvenile fish utilize mangrove habitats? Journal of Experimental Marine Biology and Ecology 257:229-253.

Larson MG, Booth DB, and Morley SA. 2001. Effectiveness of large woody debris in stream rehabilitation projects in urban basins. Ecological Engineering 18:211-226.

Levin SA. 1992. The problem of pattern and scale in ecology: The Robert H. MacArthur award lecture. Ecology. 73:1943-1967. 
MacDonald JA, Shahrestani S, and Weis JS. 2009. Behaviour and space utilization of two common fishes within Caribbean mangroves: implications for the protective function of mangrove habitats. Estuarine, Coastal and Shelf Science 84:195-201. Magurran AE. 2004. Measuring Biological Diversity. Blackwell Publishing: Oxford, UK.

McArdle BH, and Anderson MJ. 2001. Fitting multivariate models to community data: a comment on distance-based redundancy analysis. Ecology 82:290-297.

McClain C, and Barry J. 2014. Beta-diversity on deep-sea wood falls reflects gradients in energy availability. Biology Letters 10: 20140129.

Nagelkerken I, Blaber SJM, Bouillon S, Green P, Haywood M, Kirton LG, Meynecke JO, Pawlik J, Penrose HM, Sasekumar A. and Somerfield PJ. 2008. The habitat function of mangroves for terrestrial and marine fauna: A review. Aquatic Botony 89:155185.

Nurminen L, Horppila J, and Pekcan-Hekim Z. 2007. Effect of light and predator abundance on the habitat choice of plant-attached zooplankton. Freshwater Biology 52:539-548.

Petren K, and Case TJ. 1998. Habitat structure determines competition intensity and invasion success in gecko lizards. Proceedings of the National Acadamy of Science, USA 95:11739-11744.

Robertson AI, and Daniel PA. 1989a. Decomposition and the annual flux of detritus from fallen timber in tropical mangrove forests. Limnology and Oceanography 16:640646.

Robertson AI. 1990. Plant-animal interactions and the structure and function of mangrove forest ecosystems. Australian Journal of Ecology 16:433-443.

Robison B, Seibel B, and Drazen J. 2014. Deep-sea octopus (Graneledone boreopacifica) conducts the longest-known egg-brooding period of any animal. PLOS ONE 9:7.

Ronnback P, Troell M, Kautsky N, and Primavera JH. 1999. Distribution pattern of shrimp and fish among Avicennia and Rhizophora microhabitats in the Pagbilao mangroves, Philippines. Estuarine, Coastal and Shelf Science 48:223-234.

Roth BM, Kaplan IC, Sass GG, Johnson PT, Marburg AE, Yannarell AC, Havlicek TD, Willis TV, Turner MG, and Carpenter SR. 2007. Linking terrestrial and aquatic ecosystems. The role of woody habitat in lake food webs. Ecological Modelling 203:439-452.

Ruxton RD, Sherrett TN, and Speed MP. 2004. Avoiding attack: the evolutionary ecology of crypsis, warning signals and mimicry. Oxford University Press, Oxford.

Saha N, Aditya G, and Saha GK. 2009. Habitat complexity reduces prey vulnerability: An experimental analysis using aquatic insect predators and immature dipteran prey. Journal of Asia-Pacific Entomology 12:233-239.

Sanchirico JN, and Mumby P. 2009. Mapping ecosystem functions to the variation of ecosystem services: implications of species-habitat associations for coastal land-use decisions. Theoretical Ecology 2:67-77.

Shields JRFD, Knight SS, and Stofleth JM. 2006. Large woody addition for aquatic habitat rehabilitation in an incited, sand-bed stream, Little Topashaw Creek, Mississippi. River Research and Applications 22:803-817.

Shirvell CS. 1990. Role of instream rootwads as juvenile Coho salmon (Oncorhynchus kisutch) and steelhead trout (O. mykiss) cover habitat under verying streamflows. Canadian Journal of Fisheries and Aquatic Sciences 47:852-861.

Smith EK, Thatje S, and Hauton C. 2013. Thermal tolerance during early ontogeny in the common whelk Buccinum undatum (Linnaeus 1785): Bioenergetics, nurse egg partitioning and developmental success. Journal of Sea Research 79:32-39. 
Smock LA, Metzler GM, and Gladden JE. 1989. Role of debris in the structure and functioning of low-gradient headwater streams. Ecology 70:764-775.

Storry KA, Weldrick CK, Mews M, Zimmer M, and Jelinski DE. 2006. Intertidal coarse woody debris: A spatial subsidy as shelter or feeding habitat for gastropods? Estuarine, Coastal and Shelf Science 66:197-203.

Syms C, and Jones GP. 2000. Disturbance, habitat structure, and the dynamics of a coralreef fish community. Ecology 81:2714-2729.

Taylor JR, Cook MM, Kirkpatrick AL, Galleher SN, Eme J, and Bennett WA. 2005. Thermal tactics of air-breathing and on air-breathing Goboids inhabiting mangrove tidepools on Palau Hoga, Sulawesi, Indonesia. Copeia 4:886-893.

Tse P, Nip THM, and Wong CK. 2008. Nursery function of mangrove: a comparison with mudflat in terms of fish species composition and fish diet. Estuarine, Coastal and Shelf Science 80:235-242.

Valiela I, Bowen JL, and York JK. 2001. Mangrove forests: one of the world's threatened major tropical environments. Bioscience. 51:807-815.

Verweij MC, Nagelkerken I, Graaff D, Peeters M, Bakker EJ, and van der Velde G. 2006. Structure, food and shade attract juvenile coral reef fish to mangrove and seagrass habitats: a field experiment. Marine Ecology Progress Series 306:257-268.

Wang M, Huang Z, Shi F, and Wang W. 2009. Are vegetated areas of mangroves attractive to juvenile and small fish? The case of Dongzhaigang Bay, Hainan Island, China. Estuarine, Coastal and Shelf Science 85:208-216.

Warfe DM, and Barmuta LA. 2004. Habitat complexity mediates the foraging success of multiple predator species. Oecologia 141:171-178.

Willis SC, Winemiller KO, and Lopez-Fernandez H. 2005. Habitat structural complexity and morphological diversity of fish assemblages in a Neo-tropical floodplain river. Oecologia 142:284-295.

Wright JP, Jones CG, and Flecker AS. 2002. An ecosystem engineer, the beaver, increases species richness at the landscape scale. Oecologia 132:96-101.

Wright JP, and Flecker AS. 2004. Deforesting the riverscape: the effects of wood on fish 18 diversity in a Venezuelan piedmont stream. Biological Conservation 120:439-44. 


\section{Table 1 (on next page)}

Transect lengths and wood collection details.

Table 1, The range of lengths (metres) of five transects extending from the strandline, and out to the fringing edge from each mangrove forest locality, combined with the total number of wood samples collected from the five transects in each mangrove forest. 


\begin{tabular}{lrr}
\hline Site & Transect length $(\mathbf{m})$ & Number of LWD samples \\
Langira & 340 to 440 & 70 \\
Kaluku & 25 to 60 & 20 \\
Loho & 60 to 160 & 44 \\
One Onitu & 80 to 110 & 32 \\
Gili & 70 to 100 & 30 \\
\hline
\end{tabular}




\section{Table 2 (on next page)}

The range of animals in teredinid tunnels and mangrove forest details.

Table $2 \mathrm{~A}$, Animals removed from teredinid tunnels in 20 samples of wood, from each of the five mangrove forest sites. ${ }^{*}=$ present in that mangrove forest. $\mathrm{B}$, details of the five mangrove forest sites, with the total area of each forest (hectares), the total area surveyed of the combined five transects (hectares), the total volume of fallen wood found in the five transects $\left(\right.$ metre $\left.^{3}\right)$, the \% of wood used to quantify animals and teredinid attack from the total volume of wood within the five transects, and the total number of species and abundance of animals removed from 20 wood samples from each mangrove forest locality. 
$\mathbf{A}$

\begin{tabular}{|c|c|c|c|c|c|c|c|c|}
\hline Phylum & Class $\quad \frac{\overrightarrow{\frac{\sigma}{l}}}{\frac{7}{0}}$ & Family & Species & Langira & Kaluku & $\begin{array}{c}\text { SITES } \\
\text { Loho }\end{array}$ & One Onitu & Gili \\
\hline Platyhelminthes & Rhabditoph $\stackrel{\omega}{\partial \mathrm{ra}}$ & Gnesiocerotidae & Styloplanocera sp. A & & * & * & & \\
\hline Nemertea & Enopla $\quad \sum^{\bar{\sigma}}$ & Prosorhochmidae & Pantinonemertes sp. A & & $*$ & $*$ & & \\
\hline \multirow[t]{14}{*}{ Mollusca } & Bivalvia $\stackrel{\varrho}{\leftrightarrows}$ & Isognomonidae & Isognomon ephippium & * & $*$ & & & \\
\hline & $\frac{s}{d}$ & Mytilidae & Xenostrobus sp. A & * & $*$ & * & & \\
\hline & Gastropodar & Assimineidae & assimineid sp. A & & $*$ & $*$ & $*$ & \\
\hline & 3 & Cerithiidae & Clypeomorus sp. A & $*$ & & & & \\
\hline & d) & Columbellidae & Pseudanachis basedowi & $*$ & & & & \\
\hline & Q & Ellobiidae & Pythia sp. A & & & & & * \\
\hline & & Marginellidae & marginellid sp. A & & * & $*$ & $*$ & \\
\hline & & Mitridae & Strigatella sp. A & & $*$ & & & \\
\hline & & Muricidae & Thais gradata & & & & * & \\
\hline & & Nassariidae & Nassriuas sp. A & * & & & & \\
\hline & & Onchidiidae & Onchidium nigram & & $*$ & & & \\
\hline & & Pyramidellidae & pyramidellid sp. A & & $*$ & & & \\
\hline & Polyplacophora & & chiton sp. A & & & $*$ & & \\
\hline & Cephalopoda & & octopod sp. A & $*$ & & & $*$ & \\
\hline Sipuncula & Sipunculidea & Phascolosomatidae & Phascolosoma arcuatum & * & * & & & \\
\hline
\end{tabular}




\begin{tabular}{|c|c|c|c|c|c|c|c|c|}
\hline \multirow[t]{2}{*}{ Annelida } & \multirow[t]{2}{*}{ Polychaeta } & Amphinomidae & amphinomid sp. A & $*$ & $*$ & * & & $*$ \\
\hline & & Eunicidae & eunicid sp. A & $*$ & $*$ & $*$ & $*$ & \\
\hline \multirow{10}{*}{ Arthropoda } & \multirow{4}{*}{ 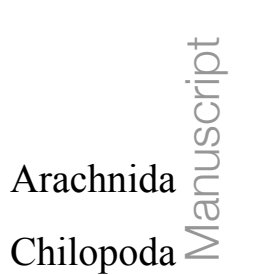 } & Nereididae & nereid spp. & $*$ & $*$ & $*$ & $*$ & \\
\hline & & Terebellidae & terebellid sp. A & $*$ & $*$ & $*$ & $*$ & \\
\hline & & Desidae & Desis martensi & $*$ & $*$ & * & $*$ & \\
\hline & & Cryptopidae & centipede sp. A & & $*$ & & & $*$ \\
\hline & \multirow{3}{*}{ 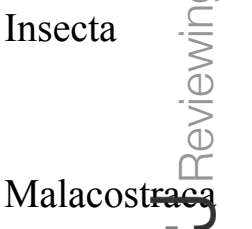 } & Cerambycidae & $\begin{array}{l}\text { cerambycid sp. A } \\
\text { Apteronemobius }\end{array}$ & $*$ & $*$ & & $*$ & $*$ \\
\hline & & Gryllidae & asahinai & & & & & $*$ \\
\hline & & Alpheidae & Alpheus sp. A & $*$ & $*$ & $*$ & & \\
\hline & (d) & Atyidae & Caridina propinqua & $*$ & $*$ & & & $*$ \\
\hline & ()) & Diogenidae & Diogenes sp. A & $*$ & $*$ & & & \\
\hline & Q & Grapsidae & Metapograpsus spp. & $*$ & $*$ & $*$ & $*$ & $*$ \\
\hline & & Xanthidae & xanthoid spp. & $*$ & $*$ & $*$ & $*$ & $*$ \\
\hline & & Cirolanidae & Cirolana sp. A & $*$ & $*$ & $*$ & $*$ & $*$ \\
\hline & & Talitridae & Microrchestia sp. A & $*$ & $*$ & $*$ & $*$ & $*$ \\
\hline \multirow[t]{4}{*}{ Chordata } & \multirow[t]{3}{*}{ Actinopterygii } & Blenniidae & blennie sp. A & & & & $*$ & \\
\hline & & Muraenidae & $\begin{array}{l}\text { Gymnothorax } \\
\text { richardsoni }\end{array}$ & $*$ & & & & \\
\hline & & Ptereleotridae & Parioglossus interruptus & $*$ & $*$ & $*$ & & \\
\hline & Ascidiacea & & tunicate sp. A & & * & & $*$ & \\
\hline
\end{tabular}




\begin{tabular}{|c|c|c|c|c|c|c|}
\hline Site & $\begin{array}{c}\text { Mangrove area } \\
\frac{\frac{2}{\frac{1}{c}}(\mathrm{ha})}{}\end{array}$ & $\begin{array}{l}\text { Mangrove area } \\
\text { surveyed (ha) }\end{array}$ & $\begin{array}{l}\text { LWD volume in } \\
\text { transects }\left(\mathrm{m}^{3}\right)\end{array}$ & $\begin{array}{c}\text { \% of LWD } \\
\text { analysed }\end{array}$ & Total species & Total abundance \\
\hline Langira & $\stackrel{\infty}{\supset} 60$ & 1 & 3.5 & 0.4 & 22 & 173 \\
\hline Kaluku & 厄 0.5 & 0.1 & 0.22 & 5.9 & 26 & 850 \\
\hline Loho & $\geq 3.1$ & 0.2 & 0.75 & 2.4 & 17 & 216 \\
\hline One Onitu & $-\frac{\digamma}{\sum} 1$ & 0.2 & 1.5 & 1 & 15 & 249 \\
\hline Gili & $\stackrel{d}{2} 1$ & 0.1 & 1 & 1 & 10 & 132 \\
\hline & $\frac{d}{\square}$ & & & & & \\
\hline
\end{tabular}




\section{Figure 1}

A range of animals within teredinid tunnels.

Figure 1, a range of animals each removed from teredinid tunnels in wood. Images: A, a developing baby octopus. B, The Reef Spider, Desis martensi, removed from within its tunnel. Further evidence of the teredinid tunnel nursery-function: the desid has an egg-sac below its abdomen. C, The exposed tentacles of an octopus with egg-sacs. D, The ventral view of a cirolanid isopod. Note the large egg-sac almost covering the pereopods. E, a megalopa (juvenile) spider crab, and F, a Richardson's Moray eel found within a teredinid tunnel. 


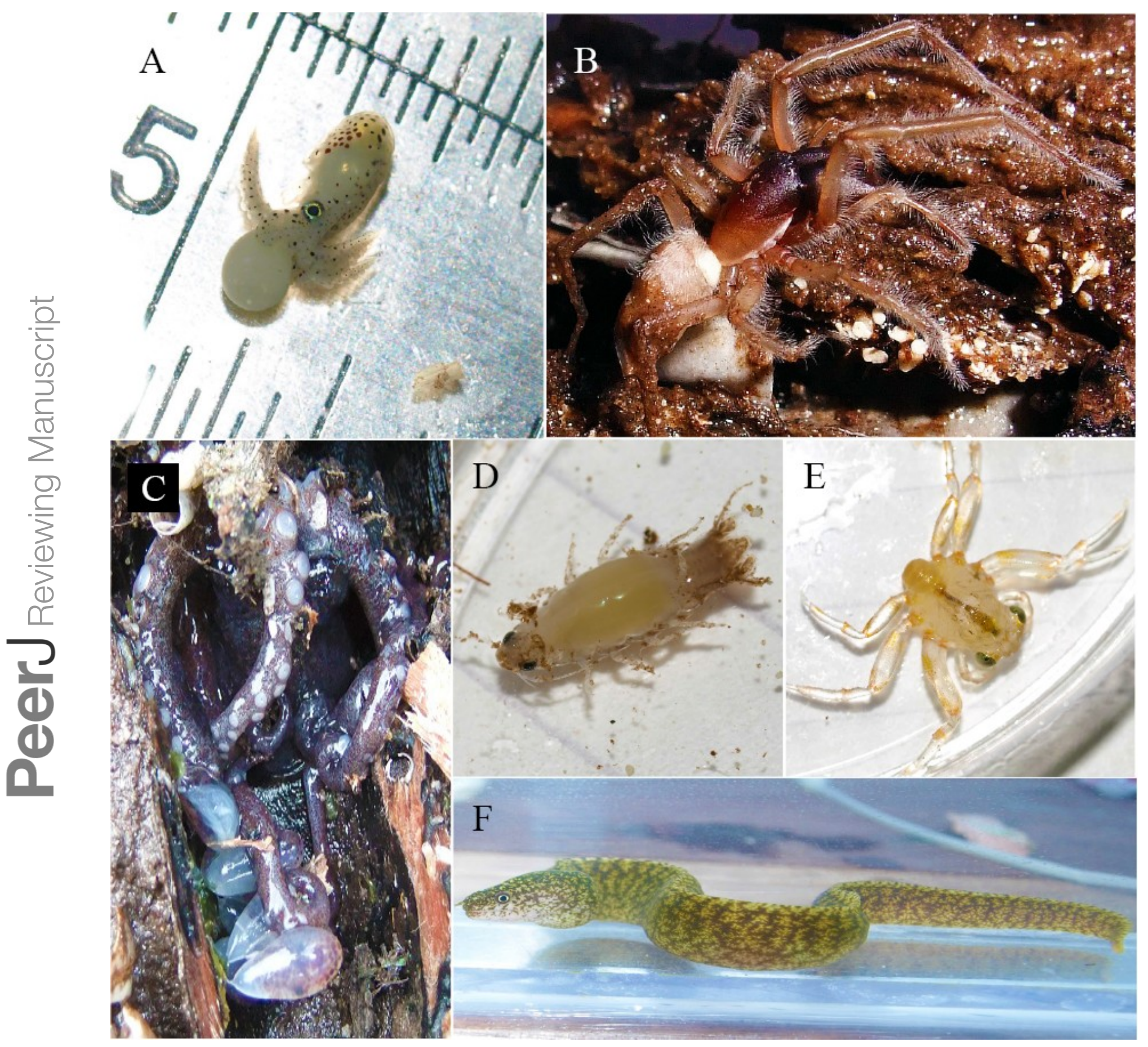




\section{Figure 2}

Multivariate ordinations of animal abundance, numbers of species and environmental variables across five mangrove forests.

Figure 2, Distance-based redundancy analysis (dbRDA) expressed as ordinations. A, the variation of teredinid-attacked wood samples analysed from five mangrove sites in, relation to; B, measured environmental variables: teredinid-attack (attack), site area, distance from land (D.F.L), substrate type, volume of wood sample ( $\mathrm{L}$ vol) and salinity. The strongest relationship explaining the scatter of wood samples is correlated with teredinid attack, and C, a strong relationship is found with the number of species and abundance of animals found in the wood samples with teredinid attack. 

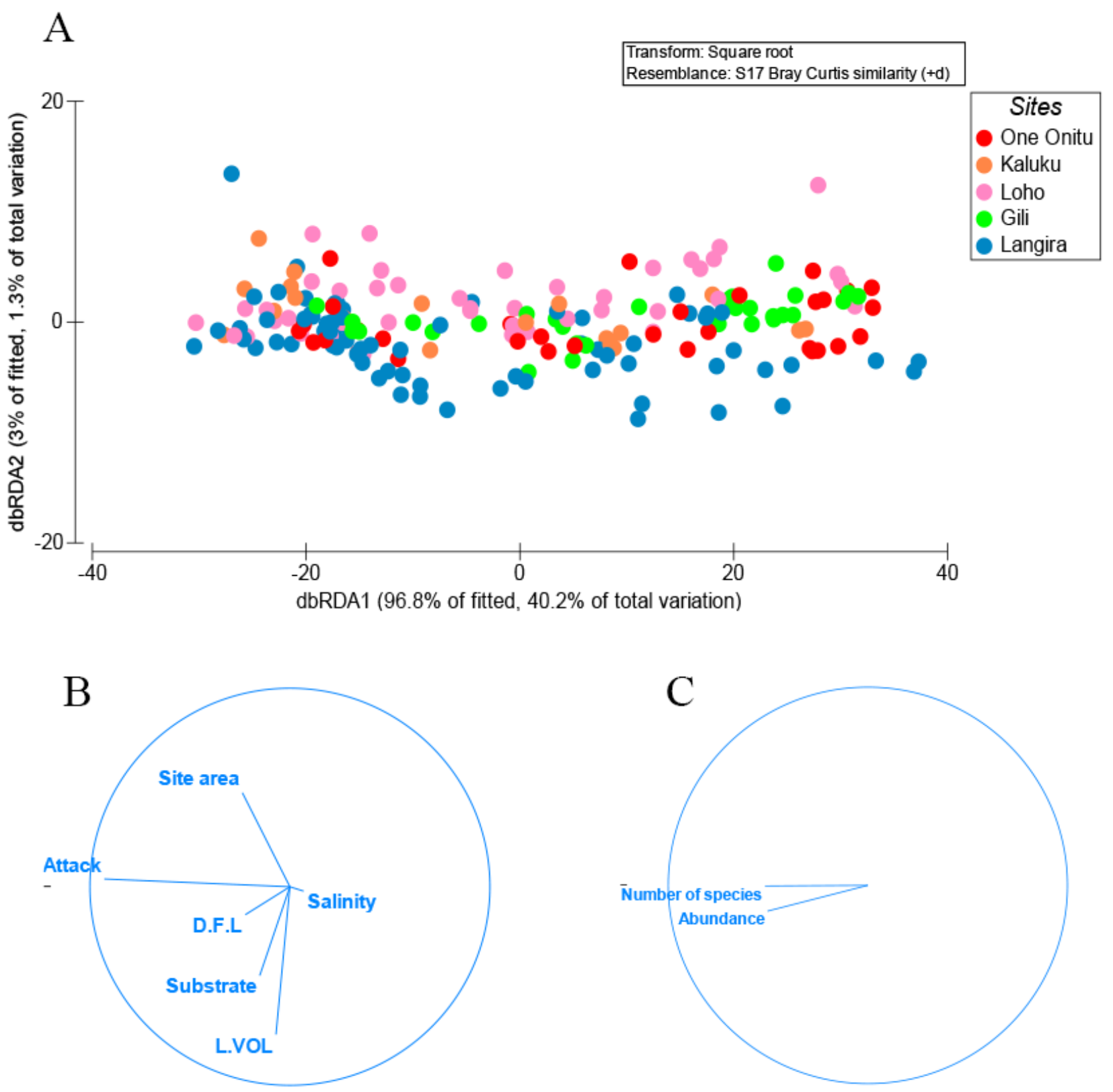


\section{Figure 3}

Differences of the abundance of, and numbers of species in wood categorised by the percentage surface area of teredinid tunnels.

Figure 3, Regression analyses and means of species and abundance of animals removed from wood exposed to different levels of teredinid attack (numbers of teredinid tunnels expressed by the percentage cross-sectional surface area of tunnels in each wood sample). A, the number of different species $(p=\langle 0.001)$, and $B$, the total abundance of animals $(p=$ $<0.001)$, within per litre volume of LWD with different levels of teredinid-attack. $C$, the mean number of different species $(p=<0.001)$, and $D$, mean abundance of animals $(p=<0.001)$ within per litre volume of LWD categorised by percentage surface area of teredinid tunnels. *Note: for each of the four categories of percentage surface area of teredinid tunnels $(0-$ $19.9 \%, 20-39.9 \%, 40-59.9 \%$ and $>60 \%$ ), twenty items of LWD were used (letters above the bars $=$ Tukey's pairwise post-hoc comparisons, mean \pm SE). 
A

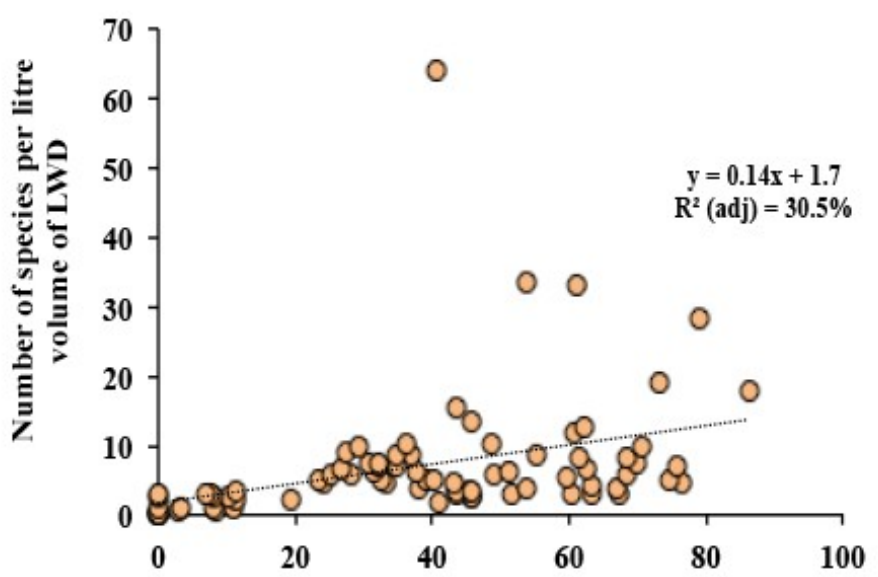

C

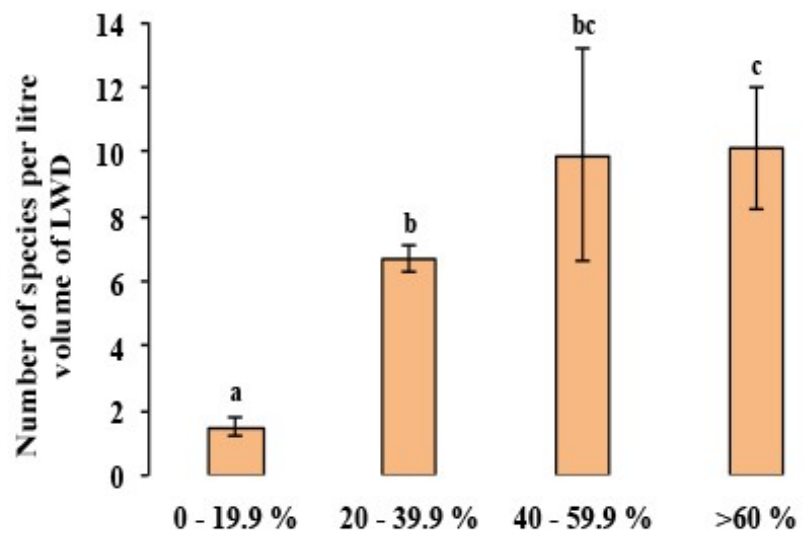

Percentage surface area of teredinid attack
B

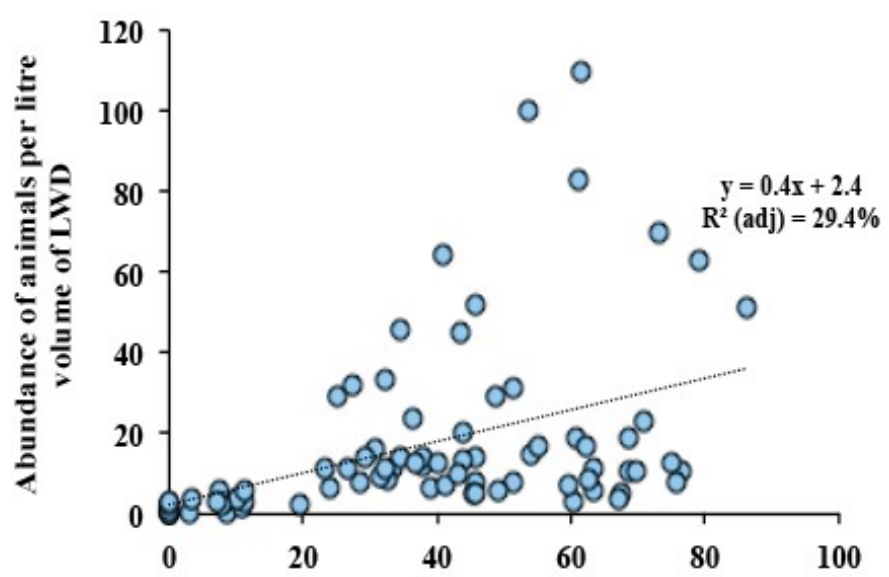

D

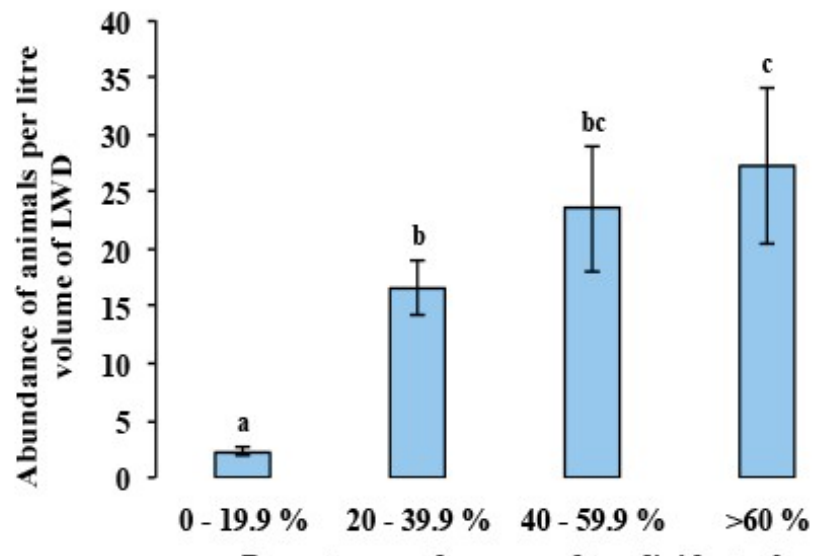

Percentage surface area of teredinid attack 


\section{Figure 4}

Mangrove forest differences of teredinid tunnels in fallen wood, emersion time and animals within tunnels.

Figure 4, The effect from vacant teredinid tunnels and emersion on five different mangrove forests. A, the percentage of cross-sectional surface area of teredinid tunnels measured in wood $(n=20)$ from each of the five mangrove forest localities $(p=\langle 0.01)$. B, emersion times $\left(h \mathrm{~d}^{-1}\right)$ within each of the five mangrove forests $(p=\langle 0.001)$. C, the abundance of animals removed and counted from samples of tunnelled wood ( $n=20$, standardised to 1 litre) within each forest $(p=\langle 0.01)$ and, $D$, the number of species also removed and counted from samples of tunnelled wood $(n=20$, standardised to 1 litre) $(p=>0.05)$ : from each of the five mangrove forests (letters above the bars $=$ Tukey's pairwise post-hoc comparisons, mean \pm $\mathrm{SE})$. 
A

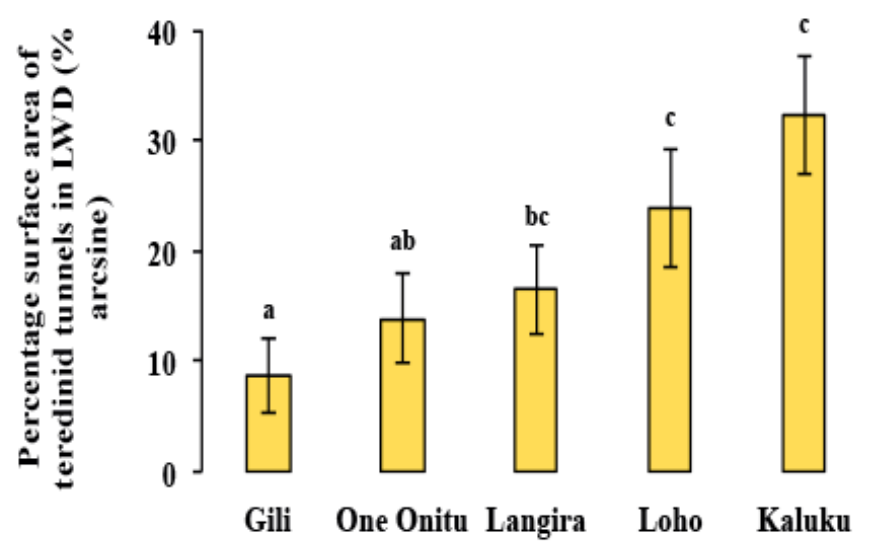

C
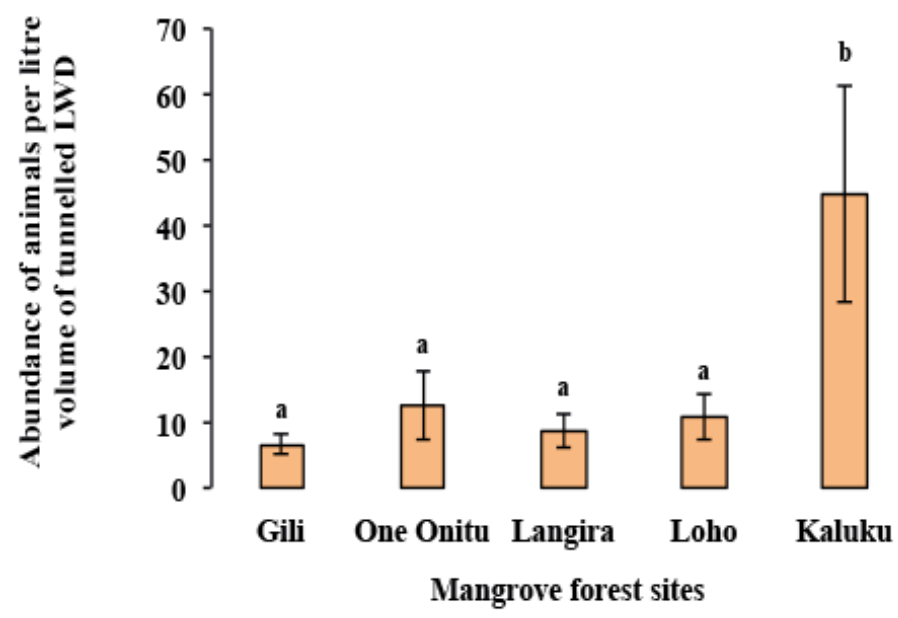

B

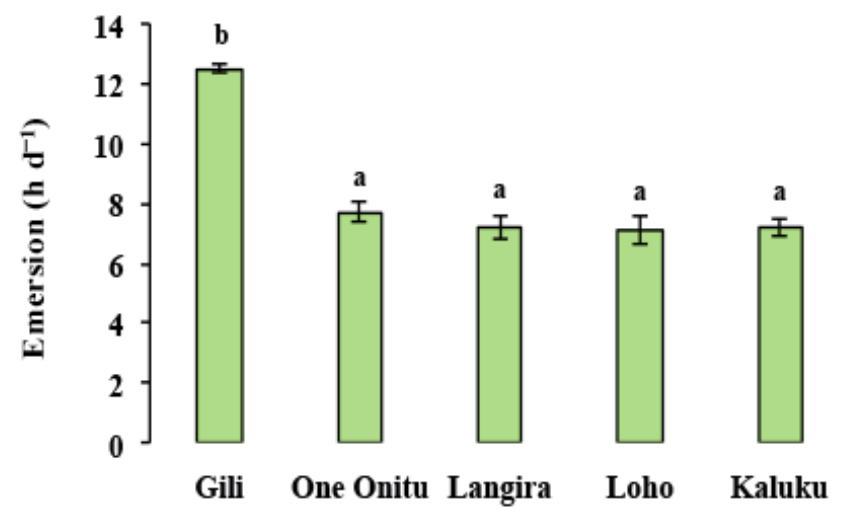

D

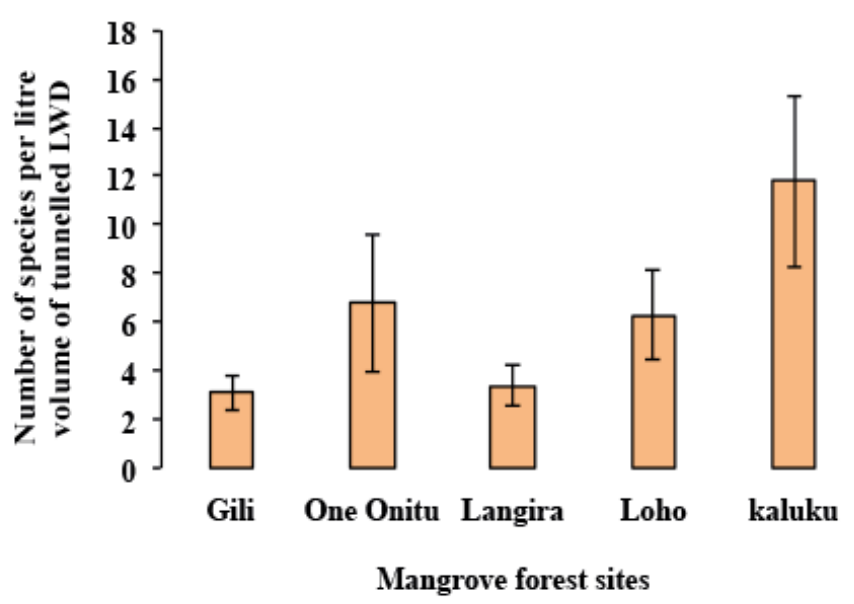




\section{Figure 5}

Differences of temperature in wood compared with outside air temperatures, and animal abundance.

Figure 5, Temperature difference in-wood compared with outside wood-surface air temperatures $\left({ }^{\circ} \mathrm{C}\right)$ of fallen logs $(n=27)$ attacked by teredinids in the Langira mangrove forest, with total counts of animals removed from samples of the same logs standardised to one litre. As outside wood-surface air temperatures peak, internal wood-temperature becomes significantly cooler with a maximum temperature difference of $>9^{\circ} \mathrm{C}$ within wood $(p$ $=<0.001)$. The abundance of animals also significantly increase with decreasing temperatures $(p=<0.05)$. 
O Temperature difference in wood $O$ Abundance of animals in wood Air temperature ${ }^{\circ} \mathrm{C}$

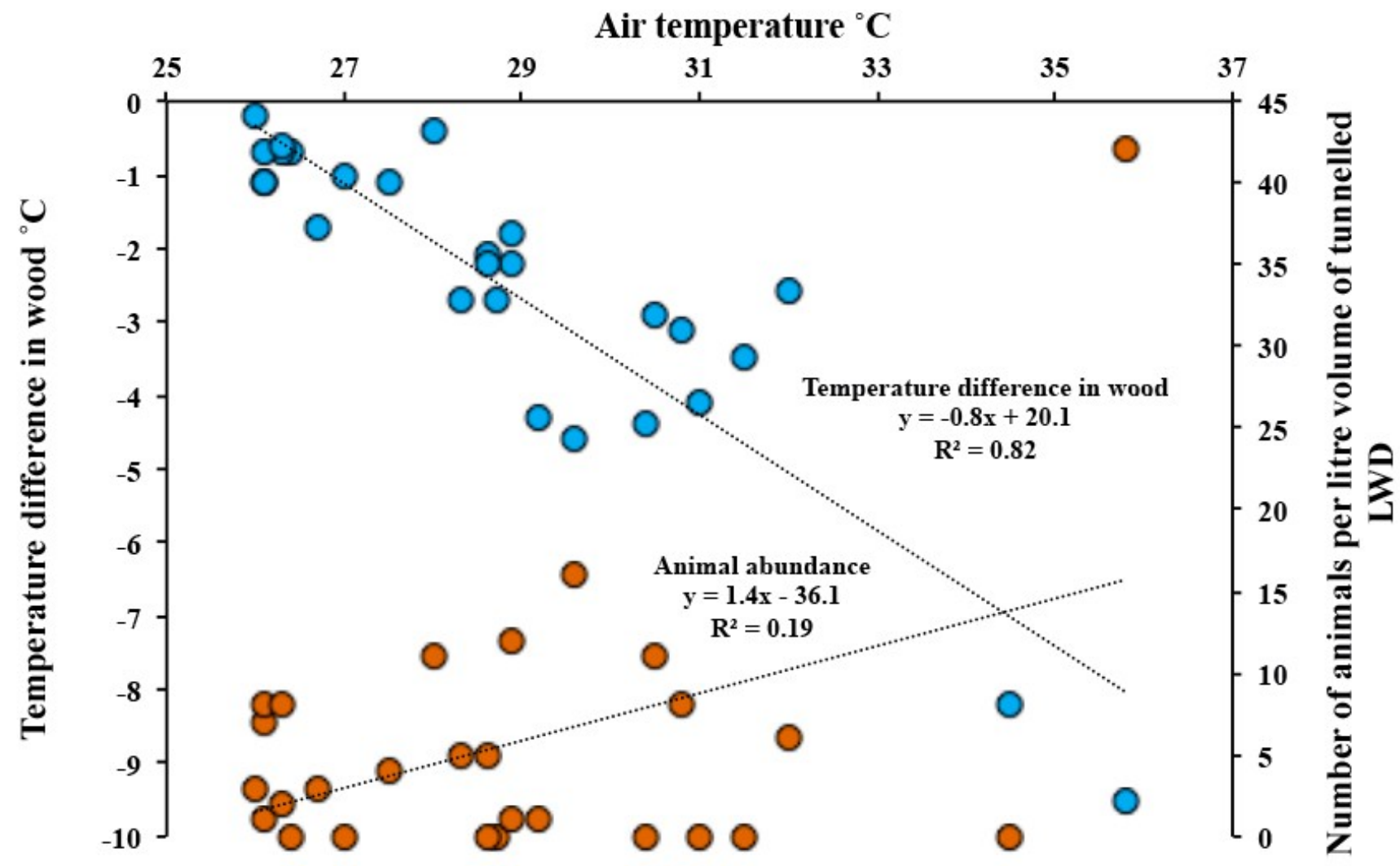

